\title{
PENINGKATAN KEMAMPUAN MEMECAHKAN MASALAH MELALUI LEMBAR KEGIATAN PESERTA DIDIK (LKPD) BERBASIS MASALAH
}

\author{
Olyvia Oshi Arestu ${ }^{1 *}$, Bhakti Karyadi ${ }^{1}$, Irwandi Ansori ${ }^{1}$ \\ ${ }^{1}$ Program Studi Pendidikan Biologi, Fakultas Keguruan dan Ilmu Pendidikan, Universitas Bengkulu \\ email: olyviaarestu@gmail.com
}

\begin{abstract}
Abstrak
Penelitian ini bertujuan untuk mengembangkan LKPD Biologi berbasis problem based learning pada materi pencemaran lingkungan dalam upaya meningkatkan kemampuan memecahkan masalah peserta didik kelas $X$ SMA. Jenis penelitian ini adalah penelitian dan pengembangan. Metode penelitian yang digunakan adalah $R$ \& D dengan mengadopsi model Dick \& Carey, yang terdiri dari 9 tahapan. Subjek penelitian adalah 31 orang peserta didik kelas X MIPA 1 SMA Negeri 1 Bengkulu Tengah. Variabel penelitian adalah kemampuan memecahkan masalah peserta didik. Instrument yang digunakan untuk mengukur kemampuan memecahkan masalah berupa tes tertulis. Hasil dari pengembangan LKPD Biologi berbasis problem based learning materi pencemaran lingkungan terdiri atas lima unsur kerangka umum dan sembilan unsur kerangka inti. Hasil penilaian validasi keseluruhan aspek pada bahan ajar LKPD Biologi berbasis problem based learning materi pencemaran lingkungan yang dikembangkan memiliki kelayakan sangat baik dengan persentase $90,62 \%$. Hasil pretest dan posttest kemampuan memecahkan masalah peserta didik sebelum dilakukan uji coba LKPD dan setelah diujicobakan LKPD menunjukkan adanya peningkatan hasil dengan rerata skor 61 menjadi 78. Maka pembelajaran dengan menggunakan LKPD Biologi hasil pengembangan problem based learning dapat meningkatkan kemampuan memecahkan masalah peserta didik pada materi pencemaran lingkungan kelas X SMA.
\end{abstract}

Kata Kunci : LKPD, memecahkan masalah, problem based learning.

\begin{abstract}
This study aimed to develop Biology Students Worksheets based on problem based learning towards Enviromental Pollution to improve problem solving ability of grade $X$ students in senior high school. The design of this research was research and development adopted from Dick \& Carey model that consists of 8 stages. Subjects of this research were 31 students in class X SMAN 1 Bengkulu City. Research variabel of this research was the problem solving skills of students. Instrument used to measured the problem solving ability was written test. The result of the development of biology students worksheet based on problem based learning in Enviromental Pollution topic consists of five elements of general framework and nine elements of core framework. The results of validation assesment on all aspects of students worksheet developed was $90.62 \%$ (very good). Data analyzed of pretest and postest score results on student's problem solving ability with implementation of Students Worksheets and without implementation of Students Worksheets were 61 and 78 respectively. Thus, implementation of developing Biology students worksheet by using the problem based learning model had increased student's problem solving ability on Enviromental Pollution topic for grade $\mathrm{X}$ senior high school.
\end{abstract}

Keyword :Students worksheet, problem solving, problem based learning. 


\section{PENDAHULUAN}

Kurikulum $2013 \quad$ menekankan pendekatan pembelajaran yang berpusat pada guru menjadi pendekatan pembelajaran yang berpusat pada peserta didik maka pembelajaran pada kurikulum 2013 mengharuskan adanya kegiatan belajar berupa real experience yang menuntut peserta didik untuk melakukan pembelajaran secara otentik. Pembelajaran otentik dapat terjadi ketika guru memberikan kesempatan belajar yang bermakna dan sesuai sehingga peserta didik dapat berfikir ilmiah, memecahkan masalah, berfikir kritis, dan merefleksi masalah dalam kehidupan seharihari. Salah satu pelajaran yang dapat langsung diaplikasikan secara real experience adalah Biologi. Biologi adalah salah satu bidang ilmu pengetahuan alam (IPA) yang menyediakan berbagai pengalaman belajar dimana peserta didik diharapkan dapat mengambil permasalahan dari dunia nyata dan menyelidikinya secara ilmiah sehingga mampu berlatih memecahkan masalah (problem solving).

Memecahkan masalah memerlukan keterampilan berfikir, termasuk mengamati, melaporkan, mendeskripsikan, menganalisis, mengklasifikasikan, menafsirkan, mengkritik, meramalkan, menarik kesimpulan, dan membuat generalisasi berdasarkan informasi yang dikumpulkan dan diolah (Nasution, 1989). Sebagai suatu kemampuan yang dimiliki oleh peserta didik maka ada beberapa indikatorindikator memecahkan masalah menurut Ennis (1985) dalam Fardani (2016) yaitu : 1) Memberikan penjelasan sederhana, 2) Membangun keterampilan dasar, 3) Membuat penjelasan lebih lanjut, 4) Merumuskan solusi alternatif, 5) Menyimpulkan.

Berdasarkan wawancara peneliti dengan guru bidang studi Biologi SMAN 1 Bengkulu Tengah diungkapkan bahwa kemampuan memecahkan masalah peserta didik kelas masih rendah, hal ini dikarenakan : 1) Peserta didik cenderung bosan diawal pembelajaran, karena materi yang diajarkan hanya sebatas konsep dan kurang memanfaatkan fasilitas yang dimiliki sekolah misalnya laboratorium, 2) Penggunaan bahan ajar salah satunya lembar kegiatan peserta didik (LKPD) belum menyisipkan fakta dan fenomena nyata dan belum memberikan kesempatan kepada peserta didik untuk melakukan kegiatan penyelidikan dan pemecahan masalah yang dapat melatih kemampuan memecahkan masalah (problem solving) peserta didik, 3) Kurangnya pemanfaatan lingkungan sebagai sumber belajar, padahal lingkungan dapat semakin memperkaya wawasan dan pengetahuan. Sebab peserta didik dapat mengalami secara langsung, mencari masalah yang ada di lingkungannya lalu memecahkan masalah tersebut.

Hasil observasi peneliti mengenai lingkungan sekitar peserta didik, ditemukan suatu permasalahan berupa perubahan fisik air sungai yang berada dekat dengan lingkungan sekolah akibat limbah industri dan adanya tumpukan sampah akibat limbah rumah tangga yang bukan berada di TPA. Oleh karena itu peneliti terdorong menjadikan permasalahan di atas sebagai sumber belajar, melalui pengembangan bahan ajar yang memiliki karakteristik dan kebutuhan peserta didik berupa lembar kegiatan peserta didik (LKPD).

Lembar kegiatan peserta didik selanjutnya disingkat LKPD, merupakan panduan untuk melatih perkembangan aspek kognitif maupun untuk mengembangkan semua aspek pembelajaran dalam bentuk eksperimen dan demonstrasi (Trianto, 2011). Menurut Depdiknas (2008), LKPD berisikan panduan kegiatan penyelidikan dan pemecahan masalah. Materi pembelajaran Biologi yang diangkat dalam LKPD yang akan dikembangkan peneliti adalah Pencemaran lingkungan untuk kelas $X$ SMA. Kompetensi dasar yang ingin dicapai yaitu 3.11 Menganalisis data perubahan lingkungan, penyebab, dan dampaknya bagi kehidupan dan 4.11 Merumuskan gagasan pemecahan masalah perubahan lingkungan yang terjadi di lingkungan 
sekitar (Permendikbud Nomor 24 tahun 2016). Materi ini dipilih dengan mempertimbangkan permasalahan yang ditemukan pada saat observasi dan berdasarkan pembelajaran berbasis masalah (problembasedlearning) yang diharapkan dari permasalahan yang berkaitan dengan materi pencemaran lingkungan dapat melatih atau meningkatkan kemampuan memecahkan masalah peserta didik.

Penelitian ini bertujuan untuk mengetahui kelayakan LKPD Biologi berbasis problem based learning dan mendeskripsikan kemampuan memecahkan masalah peserta didik setelah belajar dengan menggunakan LKPD Biologi berbasis problem based learning.

\section{METODE}

Jenis penelitian yang dilakukan adalah penelitian dan pengembangan (Research and Development (R\&D). Rancangan penelitian yang dilakukan mengadopsi pada langkah-langkah model Dick and Carey. Model Dick and Carey (2005) terdiri dari 10 langkah tetapi dikarenakan keterbatasan waktu peneliti, maka di dalam penelitian ini hanya dilakukan 8 langkah. Adapun langkah-langkah tersebut yaitu: 1) Mengidentifikasi tujuan umum pembelajaran; 2) melakukan analisis pembelajaran; 3) Mengidentifikasi tingkah laku masukan dan karakteristik peserta didik; 4) Merumuskan tujuan performansi; 5) Mengembangkan butirbutir tes acuan patokan; 6) Mengembangkan strategi pembelajaran; 7) Mengembangkan dan memilih material pembelajaran; dan 8) mendesain dan melaksanakan evaluasi formatif.

Subjek penelitian adalah peserta didik kelas X MIPA 1 SMA Negeri 1 Bengkulu Tengah berjumlah 31 orang peserta didik. Instrument yang digunakan untuk mengukur kemampuan memecahkan masalah berupa tes tertulis. Instrument untuk mengetahui kevalidan LKPD yang telah dikembangkan peneliti adalah lembar angket validasi. Penilaian validasi meliputi aspek kelayakan isi, kebahasaan, penyajian dan kegrafikan (Depdiknas, 2008). Validasi LKPD dilakukan oleh dua Dosen Ahli dan dua Praktisi (Guru Biologi). Analisis hasil penilaian validasi dilakukan dengan menghitung skor rata-rata dari setiap aspek dengan menggunakan rumus sebagai berikut:

$\bar{X}=\frac{\sum X}{n} \quad$ (Widoyoko, 2016).

Keterangan:

$\bar{X} \quad=$ Skor rata-rata keseluruhan aspek

$\sum X \quad=$ Jumlah skor yang diberikan validator

$n \quad=$ Jumlah validator

Data yang diperoleh dikonversi menjadi nilai dengan kriteria sesuai dengan Tabel 1

Tabel 1. Kriteria Kevalidan Data Hasil Penilaian

\begin{tabular}{cccc}
\hline No. & Rentang Skor & Nilai & Kategori \\
\hline 1. & $X>\bar{X}_{i}+1,8 \times S B_{i}$ & $X>62,4$ & Sangat Baik \\
2. & $\bar{X}_{i}+0,6 \times S B_{i}<X \leq \bar{X}_{i}+1,8 \times S B_{i}$ & $52,8 X \leq 62,4$ & Baik \\
3. & $\bar{X}_{i}-0,6 \times S B_{i}<X \leq \bar{X}_{\mathrm{i}}+0,6 \times S B_{i}$ & $43,2 X \leq 52,8$ & Cukup \\
4. & $\bar{X}_{\mathrm{i}}-1,8 \times S B_{i}<X \leq \bar{X}_{\mathrm{i}}-0,6 \times S B_{i}$ & $33,6 X \leq 43,2$ & Kurang \\
\hline
\end{tabular}

(Sumber: adaptasi Widoyoko, 2016).

Data keterampilan memecahkan masalah peserta didik baik secara kelompok (LKPD berbasis problem based learning) maupun individu (soal pretest-posttest) dianalisis dengan menggunakan rumus:

Persentase nilai $=\frac{\text { skor } \text { perolehan }}{\text { skor } \text { maksimum }} \times 100 \%$
Dengan kriteria kemampuan memecahkan masalah mengacu pada persentase kriteria menurut Widoyoko (2016) yang dapat dilihat pada Tabel 2. 
Tabel 2. Persentase Kriteria Kemampuan Memecahkan Masalah

\begin{tabular}{cc}
\hline Persentase & Kriteria \\
\hline $80 \%<X \leq 100 \%$ & Sangat Baik \\
$60 \%<X \leq 80 \%$ & Baik \\
$40 \%<X \leq 60 \%$ & Cukup \\
$20 \%<X \leq 40 \%$ & Kurang \\
$X \leq 20 \%$ & Sangat Kurang \\
\hline
\end{tabular}

(Sumber: adaptasi Widoyoko, 2016)

\section{HASIL DAN PEMBAHASAN}

Berdasarkan hasil analisis data angket validasi LKPD Biologi berbasis problem based learning yang telah dilakukan uji validasi oleh dua Dosen Ahli yaitu Dosen
Pendidikan Biologi UNIB, serta dua orang guru SMA Negeri 1 Bengkulu Tengah. Secara keseluruhan hasil rata-rata skor dan persentase pada tiap aspek dari tim dosen dan guru disajikan pada Tabel 3.

Tabel 3. Hasil Penilaian Rata-rata Skor dan Persentase Hasil Validasi Tiap Aspek dari Tim Dosen Ahli dan Praktisi (Guru)

\begin{tabular}{lccc}
\hline Aspek Penilaian & $\begin{array}{c}\text { Skor Rata-Rata } \\
\text { Keseluruhan }\end{array}$ & $\begin{array}{c}\text { Persentase Keidealan } \\
\text { Keseluruhan }\end{array}$ & Kategori \\
\hline Kelayakan Isi & 33,25 & $92,36 \%$ & Sangat Baik \\
Kebahasaan & 9,75 & $81,25 \%$ & Baik \\
Penyajian & 8,75 & $97,22 \%$ & Sangat Baik \\
Kegrafikan & 13,5 & $90 \%$ & Sangat Baik \\
Skor Keseluruhan Aspek & 65,25 & $90,62 \%$ & Sangat Baik \\
\hline
\end{tabular}

Hasil analisis data angket menunjukkan bahwa tiap aspek yang dinilai tim dosen dan guru, menyatakan bahwa produk LKPD yang dikembangkan berdasarkan atas problem based learning dinilai sangat baik, dengan skor rata-rata keseluruhan aspek yaitu 62,25, persentase 90,62\% sehingga produk LKPD tersebut layak untuk diujicobakan. Hal ini sesuai dengan pernyataan Darmojo dan Jenni (1992) yang menyatakan bahwa LKPD yang baik harus memenuhi syarat metodik didaktik yaitu dapat mengembangkan komunikasi sosial, emosional, estetika, pada peserta didik yang merupakan bagian kelayakan isi LKPD; syarat konstruksi yang berkenaan dengan penggunaan bahasa,kalimat di dalam LKPD; dan syarat teknis yang berkenaan dengan tulisan, gambar dan penampilan LKPD (Lestari, 2017)

Pada penelitian ini dilakukan pengukuran kemampuan memecahkan masalah yang terdiri dari 2 aspek, yaitu pengukuran kemampuan memecahkan masalah yang dilihat dari skor kinerja kelompok aspek kognitif dengan

menggunakan LKPD Biologi berbasis problem based learning materi pencemaran lingkungan yang dikembangkan peneliti dan kemampuan memecahkan masalah dilihat dari skor pretest-posttest aspek kognitif peserta didik secara individu. Adapun hasil analisis data kinerja kelompok menggunakan LKPD Biologi berbasis problem based learning disajikan pada Tabel 4. 
Tabel 4. Nilai Rata-Rata Kemampuan Memecahkan Masalah Secara Klasikal Dari Kegiatan 1 Dan Kegiatan 2 LKPD Berbasis Problem Based Learning

\begin{tabular}{clcc}
\hline No. & \multicolumn{1}{c}{ Dimensi/indikator } & Nilai rata-rata & Kriteria \\
\hline 1. & Memberikan penjelasan sederhana & 81 & Sangat Baik \\
2. & Membuat penjelasan lebih lanjut & 77 & Baik \\
3. & Merumuskan solusi alternatif & 91 & Sangat Baik \\
4. & Menyimpulkan & 73,4 & Baik \\
& Nilai rata-rata secara klasikal & 80,6 & Sangat Baik \\
\hline
\end{tabular}

Jika dilihat dari Tabel 4, kemampuan memecahkan masalah peserta didik tertinggi berada pada dimensi merumuskan solusi alternatif. Tingginya nilai yang dicapai peserta didik terutama pada dimensi merumuskan solusi alternatif tersebut tentu tidak terlepas dari LKPD yang dikembangkan berdasarkan model pembelajaran problem based learning. Problem based learning merupakan rangkaian aktivitas pembelajaran yang menekankan pada proses penyelesaian masalah yang dihadapi secara ilmiah (Sanjaya, 2008). Sehingga memotivasi peserta didik untuk menyelidiki sebuah permasalahan lebih dalam dan berusaha untuk menemukan solusi pemecahan masalah tersebut. Berdasarkan penjelasan di atas maka problem based learning dijadikan jembatan yang menghubungkan peserta didik untuk dapat melatih atau membiasakan dirinya memecahkan masalah yang disajikan.

Adapun hasil analisis data dari tes pretestposttest kemampuan memecahkan masalah dapat dilihat pada Tabel 5. Perolehan nilai rata-rata tes pretest-posttest memecahkan masalah tersebut diambil dari hasil penilaian setiap dimensi memecahkan masalah. Adapun hasil nilai rata-rata klasikal peningkatan tiap dimensi dari tes pretestposttest disajikan pada Gambar 1.

Tabel 5. Nilai Rata-Rata Tes Pretest Dan Posttest Kemampuan Memecahkan Masalah Peserta Didik

\begin{tabular}{cc}
\hline Tes & Nilai rata-rata pretest-posttest kemampuan memecahkan masalah \\
\hline Pretest & 61 \\
Posttest & 78 \\
& 17 \\
\hline
\end{tabular}




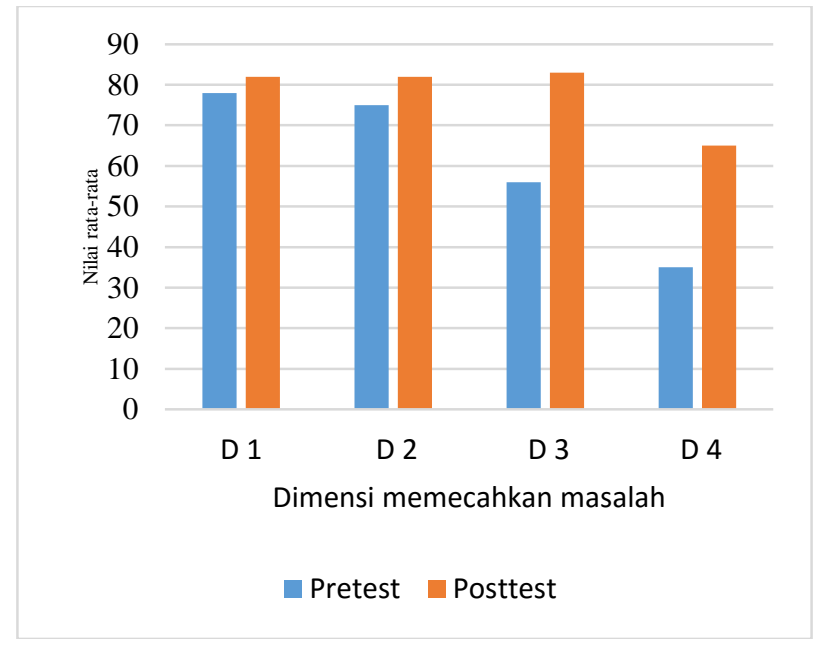

Gambar 1. Grafik persentase peningkatan kemampuan memecahkan masalah peserta didik per dimensi/indikator. D1: memberikan penjelasan sederhana; D2: membuat penjelasan lebih lanjut; D3: merumuskan solusi alternatif; dan D4: menyimpulkan.

Berdasarkan Gambar 1, grafik menunjukkan adanya peningkatan kemampuan memecahkan masalah tiap dimensi pada tes posttest. Peningkatan kemampuan memecahkan masalah pada tes posttest dikarenakan hasil kinerja peserta didik dalam mengerjakan kegiatan di dalam LKPD Biologi berbasis problem based learning yang dikembangkan peneliti sudah sangat baik, sehingga peserta didik sudah memiliki pengetahuan dan pengalaman memecahkan masalah pada tes posttest. Sejalan dengan Kurniawati (2017) yang menyatakan perangkat pembelajaran atau bahan ajar berbasis problem based learning yang dikembangkan dapat meningkatkan penguasaan klasikal karena problem based learning mengarahkan sepenuhnya kegiatan pada peserta didik seperti melakukan pengamatan pada objek nyata untuk dapat menjawab pertanyaan yang telah diungkapkan pada awal kegiatan pembelajaran. Hal ini didukung dengan pernyataan yang dikemukakan oleh Paidi (2011) bahwa masalah kompleks yang ada dalam LKPD sangat potensial untuk melatih kemampuan peserta didik dalam memecahkan masalah autentik dan menemukan alternatif solusinya (Rahayu dan Endang, 2015)

Berdasarkan hasil analisis pengukuran kemampuan memecahkan masalah peserta didik secara individu, diperoleh hasil bahwa dari keempat dimensi memecahkan masalah yang di uji cobakan pada 31 peserta didik kelas X MIPA 1 SMA Negeri 1 Bengkulu Tengah, menunjukkan persentase nilai tertinggi pada pretest maupun posttest terletak pada dimensi memberikan penjelasan sederhana. Pada dimensi memberikan penjelasan sederhana peserta didik diminta untuk menganalisis argument dari permasalahan yang disajikan pada lembar pretest maupun posttest. Tingginya nilai yang diperoleh peserta didik pada dimensi ini karena peserta didik sudah memiliki kemampuan mengidentifikasi serta mempertimbangkan suatu pendapat/informasi yang mereka dapatkan dari permasalahan yang ada sebagai suatu proses dalam memecahkan masalah. Hal ini sejalan dengan pendapat Greenstein (2012) 
yang menyatakan bahwa pemecahan masalah adalah proses dasar untuk mengidentifikasi masalah, mempertimbangkan pilihan, dan membuat pilihan berdasarkan informasi. Sedangkan rendahnya nilai yang diperoleh pada dimensi menyimpulkan tidak terlepas dari belum terbiasanya peserta didik untuk mengambil suatu keputusan terhadap suatu permasalahan dan belum mampu untuk menghubungkan variabel-variabel dari setiap fakta yang mereka peroleh. Menurut Surna dan Pandeirot (2013), karena peralihan pola fikir peserta didik yang awalnya bersifat konkret, yaitu belum memiliki kemampuan untuk memecahkan masalah verbal yang kompleks. Sedangkan dimensi menyimpulkan merupakan suatu kegiatan yang menyatukan variabel-variabel yang bersifat abstrak. Menyimpulkan dapat terjadi apabila peserta didik dapat mengabstraksikan sebuah konsep atau prinsip, yang melibatkan proses kognitif, berpusat pada penarikan pola informasi yang disuguhkan.

Secara keseluruhan hasil pengukuran kemampuan memecahkan masalah peserta didik secara individu sudah menunjukkan sebuah peningkatan, hal ini karena melalui soal yang diberikan di dalam pretest-posttest yang dikembangkan berdasarkan indikator memecahkan masalah sudah dapat menuntun peserta didik dalam belajar, mendorong peserta didik menemukan sendiri pengetahuan, dimana guru memperkenalkan suatu permasalahan yang melibatkan peserta didik untuk menggunakan konsep lalu menemukan ideide dengan menggunakan pola berfikir formal yang dapat melatih kemampuan memecahkan masalah.

Menurut teori perkembangan kognitif Piaget, peserta didik kelas $X$ SMA/MA yang berumur antara 14-15 tahun yang termasuk dalam tahap berfikir operasi formal, peserta didik mulai bergelut dengan konsep yang ada di luar pengalaman mereka sendiri, lalu masalah-masalah dapat dipecahkan melalui penggunaan eksperimentasi sistematis (Trianto,2014). Peserta didik telah mampu menunjukkan penalarannya secara mandiri dalam menganalisis masa lalu dan juga pengalaman yang sedang berlangsung. Peserta didik juga memiliki kemampuan mengaplikasikan teori dan hipotesis dalam memecahkan masalah (Surna dan Pandeirot, 2013). Hal ini juga sesuai dengan teori konstruktivisme menurut Nur (2002) yang menyatakan peserta didik dengan jenjang pendidikan SMA/MA harus bekerja memecahkan masalah, menemukan segala sesuatu untuk dirinya, dan berusaha menemukan ide-ide, guru tidak hanya memberikan pengetahuan tetapi guru juga memberikan kesempatan peserta didik untuk menerapkan ide-ide mereka sendiri (Trianto, 2014).

\section{PENUTUP}

\section{Simpulan}

Lembar kegiatan peserta didik (LKPD) hasil pengembangan dinyatakan layak untuk diujicobakan kepada peserta didik oleh tim dosen ahli dan tim praktisi (guru), karena memberikan hasil 90,62\% dengan kategori sangat baik. Dan Pembelajaran dengan menggunakan LKPD Biologi hasil pengembangan problem based learning dapat meningkatkan kemampuan memecahkan masalah peserta didik, hal ini dapat dilihat dari rerata skor kemampuan memecahkan masalah peserta didik sebelum dilakukan uji coba LKPD yaitu 61 dan setelah peserta didik belajar dengan semua kegiatan pada LKPD menunjukkan 
adanya peningkatan hasil dengan rerata skor yaitu 78.

\section{Saran}

Berdasarkan hasil penelitian yang telah dilakukan maka peneliti lanjutan perlu melakukan pengembangan terhadap dimensi kemampuan memecahkan masalah dengan cara mengembangkan indikatorindikator yang lebih tinggi dan berbeda namun disesuaikan dengan tingkat perkembangan peserta didik.

\section{Daftar Pustaka}

Depdiknas. 2008. Panduan Pengembangan Bahan Ajar SMA/MA. Jakarta: Depdiknas.

Dick, W., Carey, L., \& Carey, J. O. 2005. The systematic design of instruction (6th ed.). New York: Allyn \& Bacon, Published by Allyn and Bacon, Boston, MA. Copyright 2005 by Pearson Education. Adapted with permission from the publisher.

Fardani, Rizki Nanda. 2016. Pengaruh Kemampuan Berfikir Kritis Siswa Pada Penggunaan Modul Pembelajaran Berbasis Inkuiri Materi Suhu dan Perubahan Terhadap Hasil Belajar Siswa, (digilib.unila.ac.id/22148/3 SKRIPSI\%20, diakses tanggal 10 November 2017).

Greenstein, Laura. 2012. Assessing $21^{\text {st }}$ Century Skills. A guide evaluating mastery and authentic learning. Printed in the United States of America, Library of Congress Cataloging in Publication Data:
Copyright 2012 by Corwin a Sage Company.

Kurniawati, \& Sri Endah. 2017. Pengembangan Perangkat Pembelajaran Berbasis Problem Based Learning (PBL) Pada Mata Pelajaran Biologi Materi Klasifikasi Tumbuhan untuk Meningkatkan Kompetensi Siswa Kelas X SMA Taman Harapan Malang. (http://karyailmiah.um.ac.id/index. php/biologi/article/view/40917,Dia kses tanggal, 12 Juni 2018)

Lestari, Oktavia Dwi. 2017. Pengembangan LKPD Berbasis Problem Based Learning untuk Meningkatkan Minat dan Hasil Belajar Peserta Didik MAN Godean pada Materi Pokok Momentum dan Impuls.

Nasution, S. 1989. Kurikulum dan Pengajaran. Jakarta: Bumi Aksara.

Permendikbud nomor 24 tahun 2016 tentang Kompetensi Inti dan Kompetensi Dasar Biologi SekolahMenengah

Atas/MadrasahAliyah.Jakarta:Keme ntrianPendidikanDasardan Kebudayaan.

Rahayu Rina, \& Endang. 2015. Pengembangan Perangkat Pembelajaran IPA Berbasis Problem Based Learning di SMP. (https://journal.uny.ac.id/index.php /jk/article/view/7184, Di akses tanggal 12 Juni 2018).

Sanjaya, Wina. 2006. Strategi Pembelajaran Berorientasi Standar Proses Pendidikan. Jakarta: Kecana. 
Surna, I Nyoman., dan Pandeirot, Olga D. 2013. Psikologi Pendidikan 1. Jakarta: Erlangga.

Trianto. 2014. Mendesain Model Pembelajaran Inovatif, Progresif dan Kontekstual. Jakarta: Prestasi Pustaka Publisher.

Trianto. 2011. Model-Model Pembelajaran Inovatif Berorientasi Kontruktivistik. Jakarta: Prestasi Pustaka Publisher.
Widoyoko, Eko Putro. 2016. Evaluasi Program Pembelajaran: Panduan Praktis Bagi Pendidik dan Calon Pendidik. Yogyakarta: Pustaka Belajar). 